\title{
The Use of Batavia language in South Jakarta (Study of sociodialectology)
}

\author{
Nur Irwansyah*), \\ Universitas Indraprasta PGRI \\ Sri Mulyani, \\ Universitas Indraprasta PGRI \\ Reni Rokhayati \\ Universitas Indraprasta PGRI \\ *) Correspondences author: Jl. Raya Tengah No. 80, Kel. Gedong, Kec. Pasar Rebo, Jakarta Timur 13760; Indonesia \\ e-mail: nurirwansyah19@gmail.com
}

\begin{abstract}
This research is intended to describe some use of Betawi Language for it is native, it is speaker or those who have lived in South Jakarta for more than ten years through sociodialectology. This research scoops two goals which are (1) to describe the use of Betawi language phonologically and lexically (2) to determine similarities and differences of Betawi Language in South Jakarta. Method used in this research is descriptive comparative method. This method is suitable to compare language rolesimilarities, dialect similarities, and dialect differences in Srengseng Sawah and Ciganjur as subdistricts of Jagakarsa, Pejaten Barat as subdistricts of Pasar Minggu, Lebak Bulus and South Gandaria as subdistricts of Cilandak through phonology and lexical level.

Betawi Language contents many similarities and differences. Both cover either wholly or partially. This goes for a shortcut that each area has it is lexical and referent. Beyond that, there are two areas having differences amongst others. Yet, by statistic calculation using dialectometry, we conclude that differences occur in subdialect level.
\end{abstract}

Key Words: Betawi, Language, South Jakarta

Article History: Received: 17/10/2017; Revised: 18/11/2017; Accepted: 25/11/2017; Published: 20/12/2017

How to Cite (MLA 7th): Irwansyah, Nur, Sri Mulyani and Reni Rokhayati. "The Use of Batavia language in South Jakarta (Study of sociodialectology)." Hortatori Jurnal Pendidikan Bahasa dan Sastra Indonesia 1.2 (2017): 126-130. Print/Online. Copyrights Holder: Irwansyah, Nur, Sri Mulyani and Reni Rokhayati. First Publication: Hortatori Jurnal Pendidikan Bahasa dan Sastra Indonesia (2017).

This work is licensed under a Creative Commons Attribution-ShareAlike 4.0 International License.

\section{Pendahuluan}

Bahasa di dunia tidaklah sama. Dalam suatu negara, beragam bahasa yang dipergunakan. Bahkan pada suatu daerah tertentu beragam bahasa yang dapat kita dengar dipergunakan orang. Di Indonesia kita mengenal adanya bahasa nasional (bahasa persatuan, bahasa resmi, bahasa negara, bahasa pengantar, bahasa kebudayaan), dan juga bahasa daerah. Pada dasarnya bahasa tersebut mempunyai dua aspek mendasar, yaitu aspek bentuk dan makna. Aspek bentuk berkaitan dengan bunyi, tulisan maupun struktur bahasa, sedangkan aspek makna berkaitan dengan leksikal, fungsional maupun gramatikalnya. Apabila kita perhatikan dengan terperinci dan teliti bahasa itu dalam bentuk dan maknanya menunjukkan perbedaan antar pengungkapannya antara penutur yang satu dengan penutur yang lain. Perbedaan-perbedaan bahasa itu menghasilkan ragam-ragam bahasa atau variasi bahasa. Variasi itu muncul karena kebutuhan penutur akan adanya alat komunikasi dan kondisi sosial, serta faktor-faktor tertentu yang memengaruhinya, seperti letak geografis, kelompok sosial, situasi berbahasa atau tingkat formalitas, dan karena perubahan waktu. 
Pada dasarnya setiap bahasa yang digunakan di dunia ini memiliki variasi atau diferensiasi. Sebuah variasi dapat berwujud perbedaan ujaran seseorang dari waktu ke waktu maupun perbedaan yang terdapat dari suatu tempat ke tempat lain. Variasi-variasi tersebut akan memperlihatkan pola-pola tertentu yang disebabkan adanya pengaruh-pengaruh dari pola sosial ataupun yang disebabkan kedaerahan atau geografis. Variasi bahasa salah satunya.

Bahasa Betawi adalah bahasa yang dituturkan oleh Orang Betawi di daerah Jakarta. Bahasa ini merupakan anak dari Bahasa Melayu. Bahasa Betawi merupakan bahasa kreol (percampuran) yang didasarkan pada Bahasa Melayu Pasar ditambah unsur Bahasa Sunda, Jawa, Bali, Tiongkok bagian Selatan (terutama Hokkian), Arab, dan Eropa (terutama Belanda dan Portugis). Tidak ada struktur baku dalam bahasa ini yang membedakan dengan Bahasa Melayu karena bahasa ini berkembang secara alami. Menurut sensus tahun 1993, penutur bahasa Betawi berjumlah 2, 7 juta jiwa.

Bahasa Betawi merupakan bahasa sehari-hari suku asli ibu kota negara Indonesia, yaitu Jakarta. Bahasa ini mempunyai banyak kesamaan dengan Bahasa resmi Indonesia, yaitu Bahasa Indonesia. Bahasa Betawi merupakan salah satu anak Bahasa Melayu. Banyak istilah Melayu Sumatra ataupun Melayu Malaysia yang digunakan dalam Bahasa Betawi, seperti kata "niari" untuk hari ini. Persamaan dengan bahasa-bahasa lain di Pulau Jawa, walaupun ada bermacam-macam bahasa, seperti Bahasa Betawi, Bahasa Sunda, Bahasa Jawa, Bahasa Madura, dan lain sebagainya, tetapi hanya Bahasa Betawi yang bersumber dari Bahasa Melayu seperti halnya Bahasa Indonesia. Bagi Orang Malaysia mendengar Bahasa ini mungkin agak sedikit tidak faham karena bahasa ini sudah bercampur dengan bahasa-bahasa asing, seperti Belanda, Bahasa Portugis, Bahasa Arab, Bahasa Cina, dan banyak bahasa-bahasa lainnya. Akan tetapi, bahasa ini adalah bahasa yang termudah dimengerti oleh Orang Malaysia dibandingkan Bahasa Pulau Jawa yang lain selain Bahasa Indonesia.

Ciri khas Bahasa Betawi adalah mengubah akhiran "A" menjadi "E". sebagai contoh, Siape, Dimane, Ade Ape, Kenape. Akan tetapi, "E" di Jakarta dan Malaysia berbeda. "E" dalam Bahasa Betawi merupakan "E" dengan aksen tajam seperti "E" dalam kata "NET". Daerah lain di Indonesia yang mengubah akhiran "A" menjadi "E" adalah Sumatra Utara, Riau, Kepulauan Riau, Kalimantan Barat dan Bali walaupun tidak semua masyarakat mengubah akhiran "A" menjadi "E". Ada pula penduduk di lima daerah tersebut yang mengubah akhiran "A" menjadi "O". "E" yang digunakan di lima daerah tersebut serupa dengan "E" yang digunakan Masyarakat Malaysia. Kerajaan Tarumanagara, yang berpusat di Sundapura atau Sunda Kalapa, pernah diserang dan ditaklukkan oleh Kerajaan Sriwijaya dari Sumatra. Oleh karena itu, tidak heran kalau etnis Sunda di pelabuhan Sunda Kalapa, jauh sebelum Peristiwa Sumpah Pemuda, sudah menggunakan Bahasa Melayu, yang umum digunakan di Sumatra, yang kemudian dijadikan sebagai bahasa nasional. Karena perbedaan bahasa yang digunakan tersebut, maka pada awal abad ke-20, Belanda menganggap orang yang tinggal di sekitar Batavia sebagai etnis yang berbeda dengan etnis Sunda dan menyebutnya sebagai etnis Betawi (kata turunan dari Batavia). Walaupun demikian, masih banyak nama daerah dan nama sungai yang masih tetap dipertahankan dalam Bahasa Sunda seperti kata Ancol, Pancoran, Cilandak, Ciliwung, Cideng (yang berasal dari Cihideung dan kemudian berubah menjadi Cideung dan terakhir menjadi Cideng), dan lain-lain yang masih sesuai dengan penamaan yang digambarkan dalam naskah kuno Bujangga Manik yang saat ini disimpan di perpustakaan Bodleian, Oxford, Inggris. Meskipun bahasa formal yang digunakan di Jakarta adalah Bahasa Indonesia, bahasa informal atau bahasa percakapan sehari-hari adalah Bahasa Indonesia dialek Betawi. Bahasa daerah juga digunakan oleh para penduduk yang berasal dari daerah lain, seperti Bahasa Jawa, Bahasa Sunda, Bahasa Minang, Bahasa Batak, Bahasa Madura, Bahasa Bugis, dan juga Bahasa Tionghoa.

Pada dasarnya setiap bahasa yang digunakan di dunia ini memiliki variasi atau diferensiasi. Sebuah variasi dapat berwujud perbedaan ujaran seseorang dari waktu ke waktu maupun perbedaan yang terdapat dari suatu tempat ke tempat lain. Variasi-variasi tersebut akan memperlihatkan pola-pola tertentu yang disebabkan adanya pengaruh-pengaruh dari pola sosial ataupun yang disebabkan kedaerahan atau geografis. Variasi bahasa salah satunya.

Menurut Muhadjir, Kay Ikranegara peneliti Amerika yang bersuamikan orang Indonesia menyimpulkan hasil perhitungannya berdasarkan kosakata Swadesh bahwa 93\% kosakata dasar Bahasa Melayu kini sama dengan kosakata Bahasa Indonesia yang merupakan salah satu variasi Bahasa Melayu pula (sama-sama salah satu dari dialek Bahasa Melayu), sedangkan sisanya yang hanya sebesar $7 \%$ berasal dari Bahasa Jawa, Sunda, Bali, dan Cina.

Perbedaan mendasar dari tataran fonem antara Bahasa Betawi dan Bahasa Indonesia adalah (1) ciri pelafalan atau tata ucapnya, yaitu banyak ditemukan vokal é pada kosakata Bahasa Betawi, contohnya 
seperti pada kata apé, adé, ayé, dll., sedangkan pada Bahasa Indonesia vokal /é/ menjadi /a/ $\rightarrow$ apa, ada, saya dan (2) banyaknya suku akhir yang berakhiran « (pepet) dengan konsonan seperti: dat «y, b«k «l, bar «n, dan sebagainya. Dan pada Bahasa Indonesia $\rightarrow$ datang, bekal. Pada tataran kata perbedaan antara keduanya adalah (1) penggantian awalan me- Bahasa Indonesia dengan hanya nasal saja seperti ngambil "mengambil”, ngambek "marah", ngusir "mengusir", dan sebagainya dan (2) adanya sufiks -in dalam verba Bahasa Betawi seperti pada kata: ndatengin "mendatangi", ngumpetin "menyembunyikan", nguntitin "mengikuti", dll. Pada tataran kosakata perbedaannya antara lain adanya kata ganti orang gue dan lu, juga terdapat banyaknya kata sambung seperti dong, deh, kok, si, kek, dll. Ciri lainnya adalah dalam bahasa sehari-hari, yaitu biasanya orang Betawi menghitung dengan memakai hitungan Bahasa Cina: cepek, gopek, dll.

Pada umumnya perbedaan antara Bahasa Betawi dengan Bahasa Indonesia bersifat sistematis, sehingga kaidah-kaidah perbedaan antara keduanya bisa diketahui dengan mudah dan disusun secara sistematis. Keragaman Bahasa Betawi di atas merupakan subsistem dari bahasa yang sama. Oleh karena itu, kami tertarik untuk mengkaji dan menganalisis tentang pemakaian Bahasa Betawi di Jakarta Selatan, terutama di Kecamatan Jagakarsa, Pasar Minggu, dan Cilandak.

\section{Metode}

Metode yang digunakan dalam penelitian ini adalah metode deskritif komparatif. Istilah deskriptif menyarankan bahwa penelitian itu dilakukan semata-mata hanya berdasarkan fakta yang ada atau fenomena secara empiris hidup pada penutur-penuturnya, sehingga yang dihasilkan atau yang dicatat berupa perian bahasa yang sifatnya potret atau paparan seperti apa adanya. Istilah komparatif menyarankan pada cara kerjanya yang membandingkan data satu dengan yang lain.

Metode penelitian deskriptif komparatif dalam penelitian ini dimaksudkan untuk membandingkan kemiripan bentuk, kesamaan dialek, dan perbedaan dialek di Kecamatan Jagakarsa, yaitu di Kelurahan Srengseng Sawah dan Ciganjur, Kecamatan Pasar Minggu, yaitu di Kelurahan Pejaten Barat, dan Kecamatan Cilandak, yaitu di Kelurahan Lebak Bulus dan Gandaria Selatan melalui pengkajian perkembangannya lewat tataran fonologi dan leksikal.

Penyediaan data dilakukan dengan menggunakan metode pupuan lapangan. Metode pupuan lapangan, yaitu metode yang mengumpulkan data secara langsung atau lisan. Selain itu, metode yang digunakan adalah metode pupuan sinurat, yaitu metode yang mengumpulkan data dengan mengirimkan daftar tanyaan kepada informan. Untuk mendapatkan data yang akurat, digunakan juga metode simak dengan teknik catat dan teknik pemancingan. Teknik catat digunakan untuk mencatat jawaban atau keterangan informan. Teknik pemancingan digunakan bila data tidak muncul (kurang lengkap). Dengan demikian, dapat dikatakan bahwa penjaringan data dilakukan dengan metode observasi-partisipatif.

Data yang telah tersedia dikelompokkan sesuai dengan bidang fonologi dan leksikal beserta tipetipenya. Data yang telah diklasifikasikan itu, kemudian dibandingkan dengan Bahasa Betawi standar dengan memanfaatkan kamus dan tata bahasa baku Bahasa Betawi serta literatur Bahasa Betawi. Selanjutnya, data dianalisis untuk menemukan kekhasan Bahasa Betawi di Jakarta Selatan pada pemakaiannya sehari-hari yang telah dijaring dalam data informan. Untuk dapat menentukan sejumlah anasir termasuk bahasa, dialek, atau subdialek perlu dilakukan penghitungan atas kemunculan aspek kebahasaan. Penghitungan tersebut menggunakan dialektometri sebagai cara untuk melakukan pemilahan bahasa secara objektif. Rumus dialektometri, yaitu:

$$
\begin{array}{ll}
\frac{(\mathrm{S} \times 100)}{\mathrm{n}} & =\mathrm{d} \% \\
\mathrm{~S} & =\text { jumlah beda dengan titik pengamatan lain } \\
\mathrm{n} & =\text { jumlah kosakata yang diperbandingkan } \\
\mathrm{d} & =\text { jarak kosakata dalam persen }
\end{array}
$$

Persentase hasil penghitungan:

$$
\leq 20 \% \text { dianggap tidak ada perbedaan }
$$


$21 \%-30 \%$ dianggap ada perbedaan wicara

$31 \%$ - 50\% dianggap ada perbedaan subdialek

$51 \%$ - $80 \%$ dianggap ada perbedaan dialek

$\geq 80 \%$ dianggap sudah mewakili dua bahasa

\section{Hasil dan Diskusi}

\section{Deskripsi Data Hasil Penelitian}

Penelitian ini dilaksanakan selama Bulan November 2014 s.d. Januari 2015. Bertempat di wilayah Jakarta Selatan, yang meliputi 3 daerah penelitian, yaitu Kecamatan Jagakarsa, yaitu di Kelurahan Srengseng Sawah dan Ciganjur, Kecamatan Pasar Minggu, yaitu di Kelurahan Pejaten Barat, dan Kecamatan Cilandak, yaitu di Kelurahan Lebak Bulus dan Gandaria Selatan. Daftar tanyaan yang digunakan sebanyak 800 kata yang digunakan sebagai instrumen penelitian. Data tersebut dipergunakan untuk mengetahui perbedaan secara statistik melalui metode dialektometri.

\section{Hasil Penghitungan Data Instrumen Penelitian}

Berdasarkan data penelitian pada tabel di atas, terdapat 800 daftar kata yang digunakan. Dari hasil data tersebut diperoleh 306 kata yang berbeda di masing-masing daerah yang diteliti dan 494 kata yang sama. Oleh karena itu, hasil data penelitian di atas dapat dihitung dengan menggunakan metode dialektometri sebagai berikut.

Rumus:

$$
\begin{aligned}
& \frac{(\mathrm{s} \times 100)}{\mathrm{n}}=\mathrm{d} \% \\
& \mathrm{~s}=306 \\
& \mathrm{n}=800 \\
& \mathrm{~d}=\ldots ? \\
& \frac{(306 \times 100)}{800}=38,25 \%
\end{aligned}
$$

Dari penghitungan statistik menggunakan metode dialektometri di atas diperoleh hasil sebesar 38,25\%. Hasil ini menunjukkan bahwa dari 3 daerah penelitian di Jakarta Selatan, yaitu Kecamatan Jagakarsa, yaitu di Kelurahan Srengseng Sawah dan Ciganjur, Kecamatan Pasar Minggu, yaitu di Kelurahan Pejaten Barat, dan Kecamatan Cilandak, yaitu di Kelurahan Lebak Bulus dan Gandaria Selatan dianggap terdapat perbedaan subdialek.

\section{Simpulan}

Berdasarkan hasil penelitian yang telah kami laksanakan diperoleh simpulan bahwa terdapat beberapa persamaan dan perbedaan, baik dalam tataran fonologi, morfologi, leksikon, maupun sintaksis. Namun, dalam penelitian ini kami titik beratkan pada analisis perbedaan leksikon Bahasa Betawi di tiga kecamatan di Jakarta Selatan: Kecamatan Jagakarsa, yaitu di Kelurahan Srengseng Sawah dan Ciganjur, Kecamatan Pasar Minggu, yaitu di Kelurahan Pejaten Barat, dan Kecamatan Cilandak, yaitu di Kelurahan Lebak Bulus dan Gandaria Selatan. Dari 800 kata yang kami peroleh dari narasumber pada setiap daerah, kami memperoleh 306 perbedaan leksikon, dan 496 buah leksikon yang sama pada tiga daerah penelitian tersebut.

Bentuk pemetaan Bahasa Betawi di daerah yang kami teliti menunjukkan adanya persamaan dan perbedaan. Persamaan tersebut meliputi seluruh wilayah penelitian, maupun sebagian. Begitu pun dengan perbedaan yang terjadi meliputi seluruh wilayah penelitian, maupun sebagian. Ada yang meliputi seluruh daerah atau dengan kata lain setiap daerah memiliki leksikon atas referennya masing-masing. Ada pula 
perbedaan yang hanya meliputi dua daerah saja. Dari hasil perhitungan statistik menggunakan dialektometri, kami menyimpulkan bahwa perbedaan yang terjadi terdapat dalam tataran subdialek.

\section{Ucapan Terima Kasih}

Kami selaku tim peneliti mengucapkan banyak terima kasih kepada pihak-pihak yang telah membantu proses berjalannya penelitian ini dari awal hingga akhir dan sampai menjadi tersusunnya artikel ini. Ucapan terima kasih kami sampaikan kepada Kepala Pusat Penelitian Bahasa dan Seni Universitas Indraprasta PGRI yang telah menyetujui proposal penelitian tentang pemakaian bahasa Betawi di Jakarta Selatan ini, Ketua Program Studi Pendidikan Bahasa Indonesia Universitas Indraprasta PGRI yang telah memberikan dukungan dan doanya kepada tim peneliti, dan Para Informan di tiga kecamatan di Jakarta Selatan, yaitu Kecamatan Jagakarsa, Kecamatan Pasar Minggu, dan Kecamatan Cilandak, yang telah membantu memberikan data penelitian yang dibutuhkan oleh tim peneliti.

\section{Daftar Rujukan}

Ayatrohaedi. Dialektologi. Jakarta: Depdikbud, 1979.

Fernandez, lnyo Yos (koord). Sosiodialektologi Diakronis. Laporan Praktik Studi Lapangan Mahasiswa S2 UGM Yogyakarta, 1992.

Fernandez, lnyo Yos (koord). Dialektologi. Yogyakarta: Program Pascasarjana UGM, 1993/1994.

Fischer, John L. Social Influences on the Choice of a Linguistic Variant. Word 14. 46-47, 1985.

Giglioli, Pier Paolo. (Peny). Language and Social Context. Harmondsworth, Middlesex England: Penguin Books Ltd., 1972.

Halliday, M.A.K. "The User and The Use of Language”, Fishman, J.A. (ed), Reading in the Sociology of Language. MoutonThe Hauge: Paris, 1968.

Holmes, Janet. An Introduction to Sociolinguistic. London: Longman, 1994

Labov, William. Sociolinguistic Patterns. Philadelphia: University of Pensylvania Press, 1977.

Muhadjir, dkk. Fungsi dan Kedudukan Dialek Jakarta. Jakarta: Pusat Pembinaan dan Pengembangan Bahasa Departemen Pendidikan dan Kebudayaan, 1979.

Muhadjir .Morfologi Dialek Jakarta. Jakarta: Penerbit Djambatan, 1984.

Muhadjir. Bahasa Betawi Sejarah dan Perkembangannya. Jakarta: Yayasan Obor Indonesia, 2000.

Nababan, P.W.J. Sosiolinguistik, Suatu Pengantar. Jakarta: Gramedia, 1984.

Nothofer, Bernd. Dialektatlas Von Zentral-Java. Wiesbaden: Otto Harranssowitz, 1981.

Nothofer, Bernd. "Cita-Cita Penelitian Dialek". Dalam Dewan Bahasa, 1987.

Samsuri. Analisa Bahasa. Jakarta: Erlangga, 1982.

Sudaryanto. Metode dan Teknik Analisis Bahasa. Yogyakarta: Duta Wacana University Press, 1993.

Wardhaugh, Ronald. An Introduction to Sociolinguistic. Cambridge USA: Basil Blackwell, 1986. 